\title{
A Study on the EIS Market of Chinese SMEs
}

\author{
Lei Zhang ${ }^{1}$, Zhanhong $\mathrm{Xin}^{2}$, and Jiantong $\mathrm{CaO}^{3}$ \\ $1 \mathrm{PhD}$ candidate, The Economics and Management School, Beijing \\ University of Posts and Telecommunications, \\ No. 10 Road Xi tucheng, Haidian District, Beijing, P.R. China. \\ zhang_lei23@163.com \\ 2 Vice Dean, The Economics and Management School, Beijing \\ University of Posts and Telecommunications. xinzhanhong@263.net \\ 3 Instructor, The Economics and Management School, Beijing \\ University of Posts and Telecommunications. tony000@263.net
}

\begin{abstract}
The current Chinese EIS market is focusing on exploiting the purchase potential of the SMEs. On the basis of rare research made in this field, this paper, aiming at capturing an objective investigation, presents three aspects to illustrate the application of EIS in Chinese SMEs' market. First, several major EIS vendors are introduced, together with their reputed EIS products, and the comparison between foreign vendors and domestic ones is also made. Next, the investigation is addressed from the consumer side, portraying the profile of SMEs. Finally, this paper are put forward suggestions for the EIS vendors to develop applicable EIS for the SMEs.
\end{abstract}

\section{Introduction}

The great progress on application of enterprise information systems (EIS) has turned out to be a crucial impetus on economic development in China. The function of EIS market at past was mainly served on the needs of large enterprises, bank systems, etc. The recent problem is that these markets have been gradually entering the maturity stage of product life cycle, resulted in a budget shift of large enterprises from the purchase of IT software into the spending on update and maintenance. Therefore, the marketing of EIS sets emphasis into the field of small and mediumsized enterprises (SMEs). This paper objectively illustrates the situation of EIS market of Chinese SMEs from both supply and demand sides.

Please use the following format when citing this chapter:

Zhang, L., Xin, Z., Cao, J., 2006, in International Federation for Information Processing, Volume 205, Research and Practical Issues of Enterprise Information Systems, eds. Tjoa, A.M., Xu, L., Chaudhry, S., (Boston:Springer), pp.649-653. 


\section{Supply Side: Mainstream EIS Vendors}

In Chinese EIS market, the total amount of software vendors achieves more than 8700 , including foreign vendors and indigenous ones, but most of market share is occupied by a few influential ones[1]. Those elite incisively capture the trend of EIS market, and promote successively new products pertinently for SMEs. The leading ones are, to list a few, UFIDA, Kingdee, LangChao, Microsoft, Oracle, SAP, the former three of which are all indigenous vendors, and the latter three are the foreign ones. Their reputed products special for SMEs are listed in the Table 1.

Table 1. The Mainstream EIS Vendors and Their Products for SMEs

\begin{tabular}{|c|c|c|c|}
\hline Companies & Products & Key Features & Prices \\
\hline UFIDA & $\begin{array}{l}\text { U8 Business } \\
\text { Application } \\
\text { Suite }\end{array}$ & $\begin{array}{l}\text { Integrates modules of financial, supply chain, } \\
\text { manufacturing, BI/decision support; } \\
\text { Provides connectivity to PDM, bar-coding, SMS } \\
\text { system and mobile offices. }\end{array}$ & $\begin{array}{l}200,000- \\
500,000 \\
\text { RMB }\end{array}$ \\
\hline \multirow{2}{*}{ Kingdee } & Kingdee KIS & $\begin{array}{l}\text { Family members: Mini Edition, Standard Edition, } \\
\text { Professional Edition and Administration Edition; } \\
\text { Integrates modules of purchasing, sales, salary, report, } \\
\text { inventory, accounting, logistics, and contract. }\end{array}$ & $\begin{array}{l}3,000- \\
200,000 \\
\text { RMB }\end{array}$ \\
\hline & Kingdee $\mathrm{K} / 3$ & $\begin{array}{l}\text { Applicable to Chinese enterprises in growing phases; } \\
\text { Solutions for financials, SCM, HR, CRM, KM, and } \\
\text { manufacturing; } \\
\text { Based on Windows Distributed Internet Application. }\end{array}$ & $\begin{array}{l}100,000 \\
400,000 \\
\text { RMB }\end{array}$ \\
\hline LangChao & $\begin{array}{c}\text { LangChao } \\
\text { ERP/my GS } \\
\text { Express }\end{array}$ & $\begin{array}{l}\text { Sub-series of LangChao ERP/myGS; } \\
\text { Covering: purchasing, storage, logistics, sales, } \\
\text { accounting, manufacturing; } \\
\text { Smoothly updated to LangChao ERP/myGS pSeries; }\end{array}$ & $\begin{array}{l}30,000 \\
\mathrm{RMB}\end{array}$ \\
\hline \multirow[b]{2}{*}{ Microsoft } & $\begin{array}{c}\text { Office Small } \\
\text { Business } \\
\text { Edition } 2003\end{array}$ & $\begin{array}{l}\text { Including } 5 \text { programs: Word } 2003 \text {, Excel } 2003 \text {, } \\
\text { PowerPoint 2003, Outlook } 2003 \text { with Business } \\
\text { Contact Manager, Publisher 2003; } \\
\text { Integrate with SharePoint Services, enabling file } \\
\text { sharing and collaboration. }\end{array}$ & $\begin{array}{l}1701- \\
3822 \\
\text { RMB }\end{array}$ \\
\hline & $\begin{array}{l}\text { Windows } \\
\text { Small } \\
\text { Business } \\
\text { Server 2003 }\end{array}$ & $\begin{array}{l}\text { Standard Edition including: Server 2003, SharePoint } \\
\text { Services, Exchange Server } 2003 \text { Technology, Outlook } \\
\text { 2003, Shared Fax Service, Routing and Remote } \\
\text { Access Service; } \\
\text { Premium Edition including: ISA Server } 2000 \\
\text { Technology, SQL Server 2000, FrontPage 2003. }\end{array}$ & $\begin{array}{l}5509- \\
43,300 \\
\mathrm{RMB}\end{array}$ \\
\hline Oracle & $\begin{array}{l}\text { Oracle E- } \\
\text { Business } \\
\text { Suite Special } \\
\text { Edition } \\
\end{array}$ & $\begin{array}{l}\text { Including modules: Financials, Inventory, Purchasing, } \\
\text { Order, Discrete Manufacturing, Sales and Service, } \\
\text { and E-Business Intelligence; } \\
\text { Fully integrated solution built on the Oracle Database. }\end{array}$ & $\begin{array}{l}438,000- \\
658,000 \\
\text { RMB }\end{array}$ \\
\hline \multirow[b]{2}{*}{ SAP } & $\begin{array}{c}\text { SAP } \\
\text { Business One }\end{array}$ & $\begin{array}{l}\text { Covering: Financials, Sales, Service, Manufacturing, } \\
\text { Inventory, Purchase; } \\
\text { Easily integrate modifications into new versions. }\end{array}$ & \multirow[t]{2}{*}{$\begin{array}{l}880,000 \\
\text { RMB }\end{array}$} \\
\hline & $\begin{array}{l}\text { mySAP All- } \\
\text { in-One }\end{array}$ & $\begin{array}{l}\text { A prepackaged, industry-specific version of mySAP } \\
\text { Business Suite, and adaptability to powerful solutions; } \\
\text { Fully integrated business management applications; } \\
\text { Support for e-business and collaboration. }\end{array}$ & \\
\hline
\end{tabular}

Sources: All of information in this Table is cited from the website of each company [2-7]. 
According to SIC [1], the foreign software providers occupy most shares of system software and support software, leaving small portion of software market, such as financials software and anti-virus software, to domestic vendors. Recently, when SMEs has gained considerable attention, there are opportunities for domestic EIS vendors to win out from the new round of competition. The followings compare the strength and the weakness of both domestic EIS vendors and the foreign ones.

First, the framework of EIS products is similar, but the quality is unknown. It is obviously shown in table 1 that either the domestic EIS products or the foreign ones cover similar modules. The classification of modules is easy to copy, because it is the exoteric achievement of modern management theory. However, whether a system comfortable or not relies on its usage not just its framework. Even though the products would superficially look the same, their performance may differ far away, for instance, whether the system runs speedy and stable.

Second, the price is relatively low for the domestic ones. China is world-known for its cheap labor cost, which in turn depresses the price of output. This can be seen explicitly from the price comparison in table 1. Except for the Microsoft series, the other two foreign companies' products are nearly twice priced than the two largest domestic EIS providers. The peculiarities of SMEs determine that they would allocate a small proportion of profits to EIS, but not implies that they would choose the low-priced ones at compensation of low-quality.

Finally, even though lack of experience, the domestic vendors take advantage of convenient communication with Chinese SMEs. The foreign vendors have long years' practice, while, the domestic ones are often freshman compared with their large rivals. The strength of indigenous EIS vendors lies in convenient communication with domestic SMEs, which plays a crucial role in figuring out the actual demands of SMEs, and leads to the design of suitable EIS for SMEs.

\section{Demand Side: Profiles of SMEs}

According to Zhang [8], the official criteria setting down for SMEs are as the followings: the work force is lower than 2000 , or the total sale is less than 300 millions $\mathrm{RMB}$, or the total asset value is below 400 millions RMB; meanwhile, to be a middle sized one, the work force, the total sale and the total asset value of which must reach 300,3 millions $\mathrm{RMB}$, and 4 millions $\mathrm{RMB}$, respectively; and the remain accounts for the small sized enterprises.

On the basis of these criteria of SMEs, this report [8] also offers the distribution of SMEs by area and by industry: the SMEs are located centrally in the east littoral, and the number of SMEs there reaches 133932, while, that number in the middle area is 36548 , and the west area covers 23758 . The largest five areas are Shanghai, Shandong province, Jiangsu province, Zhejiang province, and Guangdong province, which totally account for more than a half number of the whole SMEs; Among those SMEs, the manufacturing industry takes up a large proportion achieves 179520 . 
Even though there is an immense potential in the EIS market serving for Chinese SMEs, the peculiarities of Chinese SMEs lay some hindrance on the development of appropriate EIS. The first barrier is the lack of approval from the manager, as mentioned by Cai and $\mathrm{Du}[9]$. The small scale of SMEs indicates that the companyclass decision is always made by the top manager him/herself, who are often the founder of the company, and are aware of where each dollar goes. Only if they could recognize the benefits of employing EIS, would they invest in EIS products.

Second, the SMEs are often held back by the cost and time it takes to implement EIS. To implement a system, there must be some assistant deployment. First is the basic equipment, such as computers and servers, then, the company should purchase proper software, and the last but crucial one is the possession of professionals to utilize the EIS. Only when a certain SME satisfies the three criteria could it operate the system effectively, but the problem is that each deployment appeals for money and time, which are often restricted by the scale of SMEs.

The last obstacle is how to customize for enormous SMEs. The former EIS market was concentrated on the large corporations, and the EIS providers often surveyed the actual requirements and designed the suitable systems according to the business process of the large customer. Usually, each order of large customer may reach millions of dollars, which could sufficiently compensate the customized service. However, this is not the case in the EIS market of enormous SMEs with diverse favors. The challenge comes out to be the exploration of balance between providing favorable EIS and lowering cost simultaneously.

\section{Requirements for Suitable EIS}

The EIS market of SMEs is still worthy to exploit, and the victory exists in consistent quality improvement together with continuous product innovation. There are three requirements on the development of EIS. First is to start from high point by adopting ICT. The main advantage supporting the progress is the movement of information communication technology (ICT). According to Piet and Petra [10], ICT is "seen as a modern catalyst for innovation," and they propose "the use of a network of SMEs, industry organizations, intermediary parties and knowledge institutes, to achieve adoption of new information and communication technologies."

Initially, the design of EIS was relied heavily on IT, and the function of EIS was merely to improve efficiency of the daily tasks limiting within the company, while the growing employment of CT enables various channels for communication in the outside transactions. Besides, spending no sunk cost on the outdated EIS, the SMEs could easily adopt the latest technology, and to win from the high starting point.

The second requirement is to focusing on each industry instead of each company by unifying industry standards. The hindrance for the EIS vendors to provide customized EIS is raised by the enormous quantity of SMEs with relatively small scale. As pointed out by Kingdee [11], "The application of EIS is not simply to transform the information electronically, but much more significantly is to promote 
the level of management." The tremendous quantity of SMEs prevents to develop customized EIS for each company, and the small scale ordinarily implies inadequacy in business process. Therefore, the solution is to focus on each industry instead of each company, by setting unified industry standards, aiming at to reduce the inefficiency and to improve the transaction.

The last requirement is to construct solid EIS foundation through information resource planning. The separate EIS developed before locks the information into silos, and the consequence is the repeated importing of same data, the frequent delay of information transmission, and the ceaseless updating of systems. One settlement is proposed by Gao [12], that is information resource planning (IRP), which is " $A$ holistic information planning which covers the overall management of information, from collecting, organizing, storing, transmitting, to utilizing of information gathering from diverse channels." The core of IRP is to construct basic standards of information resource management, including the holistic data planning, and execute rigorously those standards in the development of EIS.

\section{Conclusion}

The field of Chinese SMEs has recently attracting the attention from EIS vendors, who successively promote pertinent products. However, the winners must be those who attach importance to consistent quality improvement and continuous product innovation.

\section{References}

1. State Information Center (SIC), and China Information Industry Association (CIIA), edited, China Information Almanac (China Information Almanac Press, Beijing, 2004), p.29.

2. The website of UFIDA冋http://www.ufsoft.com.cn/.

3. The website of Kingdee $\square$ http://www.kingdee.com/index.jsp.

4. The website of LangChao $\square$ http://www.langchao,com.cn/.

5. The website of Microsoft $\square$ http://www.microsoft.com/china/.

6. The website of Oracle $\square$ http://www.oracle.com $/ \mathrm{global} / \mathrm{cn} /$.

7. The website of SAP $\square$ http://www. sapchina.com/.

8. J. Zhang, et al., editors, The Report of China SME Development (China Social and Scientific Documents Publishing House, Beijing, 2005), p. 3 and pp. 33-38.

9. G. Cai and Z. Du, The Current Situation and Strategy of Chinese SMEs' Informatization, Science and Technology Management Research 8, 1000-7695 (2005).

10. P. Boekhoudt and P. van der Stappen, The ASPect Project Case: a Model for SME Adoption of ICT Innovation, In the Proceedings of the $6^{\text {th }}$ International Conference on Electronic Commerce (ACM Press, New York, 2004).

11. Kingdee Software (China) Company Ltd, edited, The Integrated Application of ERP System (Tsinghua University Press, Beijing, 2005), pp. 15-21.

12. F. Gao, Information Resource Planning (Tsinghua University Press, Beijing, 2002). 